\title{
Low Wind Speed Technology Phase Il: Developing Techniques to Evaluate the Designs and Operating Environments of Offshore Wind Turbines in the Mid-Atlantic and Lower Great Lakes Regions
}

\section{AWS Truewind, LLC}

Project Description: Coastal and offshore locales are favored regions for wind power use because of their generally high wind resource and low surface roughness. Offshore sites in the United States have recently attracted considerable attention; however, few representative observations have been made.

The objective of this study is to characterize the offshore wind and wave environments of the Atlantic and lower Great Lakes regions by estimating the available wind power resource in the offshore environment and performing physically consistent modeling of the dynamics within and above the air-sea interface. The results will help the offshore wind industry more precisely quantify the design load conditions at specific sites, which will enable projects to be engineered and operated more cost effectively and with lower risk. The study will combine:

- An assimilation of monitoring and observation network data

- A six-month intensive field measurement campaign at an offshore platform

- A modeling analysis and verification study of the coastal wave and meteorological regimes

- Initial steps toward the development of a buoy-adapted atmospheric profiling system

$\begin{array}{ll}\text { Project Type: } & \text { Conceptual Design Study } \\ \text { Total Project Budget: } & \$ 600,000 \\ \text { Industry Cost Share: } & \$ 400,000 \text { (\$200,000 LIPA, } \$ 200,000 \text { NYSERDA) } \\ \text { DOE Cost Share: } & \$ 200,000\end{array}$

Planned Project Duration: September 2004-December 2005

Contacts:

NREL:

Walt Musial, NREL

1617 Cole Blvd.

Golden, Colorado 80401

AWS Truewind, LLC:

Bruce Bailey, AWS Truewind, LLC

CESTM, 251 Fuller Road

Albany, New York 12203

303-384-6956

518-437-8659

walt_musial@nrel.gov

bbailey@awstruewind.com

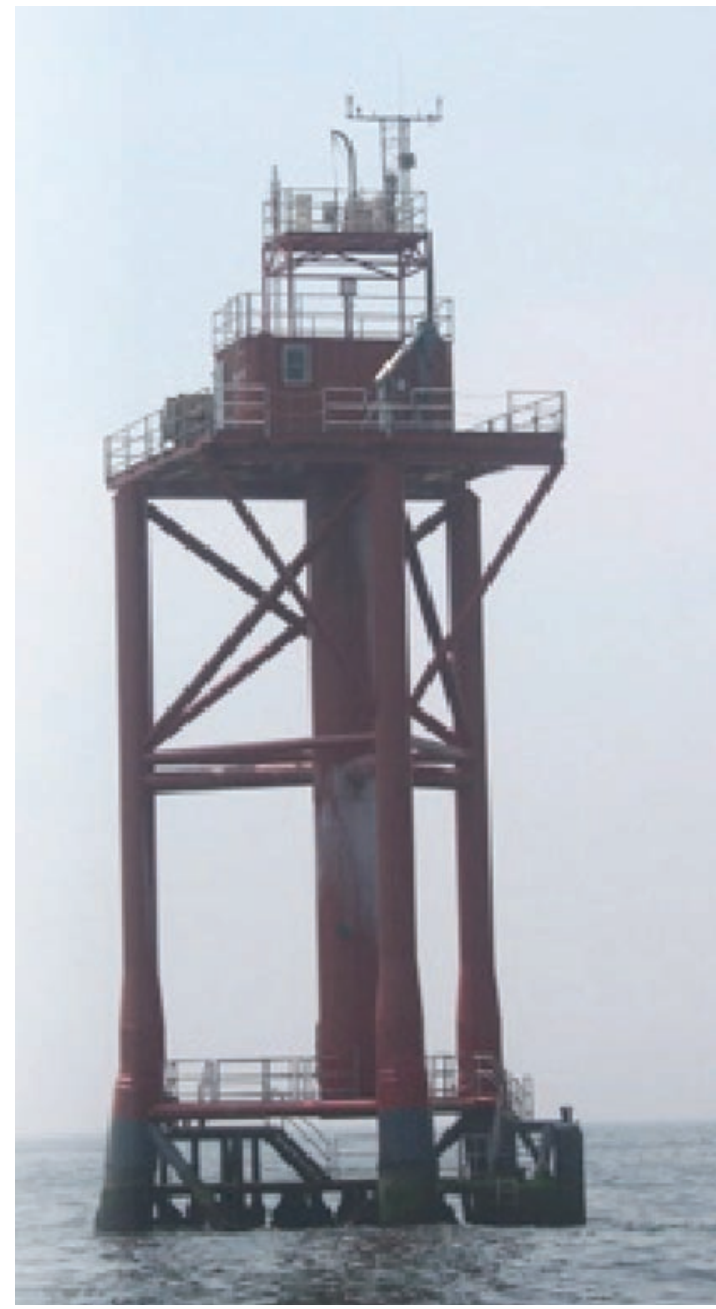

Meteorologic equipment on Ambrose light station collects the wind and wave data used for the reference database.

Current Status:

Project Underway

\begin{abstract}
A Strong Portfolio for a Strong America • Energy efficiency and clean, renewable energy will mean a stronger economy, a cleaner environment, and greater energy independence for America. Working with a wide array of state, community, industry, and university partners, the U.S. Department of Energy's Office of Energy Efficiency and Renewable Energy invests in a diverse portfolio of energy technologies.
\end{abstract}

For more information contact EERE Information Center • 1-877-EERE-INF (1-877-337-3463) • www.eere.energy.gov 